\title{
Karakterisasi Ekstrak Etanol Buah Citrus amblycarpa (L), Citrus aurantifolia (S.), dan Citrus sinensis (O.)
}

Andhi Fahrurroji ${ }^{1}$, Hafrizal Riza ${ }^{2}$

${ }^{1}$ Departemen Farmasetika dan Teknologi Farmasi, Fakultas Kedokteran, Universitas Tanjungpura, Pontianak, Indonesia

${ }^{2}$ Departemen Kimia Farmasi, Fakultas Kedokteran, Universitas Tanjungpura, Pontianak, Indonesia

*Corresponding author: roji_apt@ @pharm.untan.ac.id

Submitted: 28 Maret 2020

Accepted: 14 Juli 2020

Published: 30 November 2020

\begin{abstract}
Background: Sweet citrus fruits (Citrus amblycarpa (L)), lime (Citrus aurantifolia (S.)), and sambal orange (Citrus sinensis (O.)) have enormous potential, especially the content of secondary metabolite compounds. Objective: This study aims to determine the specific and non-specific characteristic of extract from various citrus fruits in $60 \%$ ethanol solvent. Methods: the extract obtained was determined by nonspecific parameters and the extract's specific parameters from each extract of the citrus fruit component. Results: Based on the observations' results, ethanol extract of 60\% peel and seeds and water on the citrus fruit, the highest yield value was obtained in the ethanol extract of $60 \%$ sambal orange seeds $25.28 \%$. All samples contained phenolic and flavonoid compounds in the test tube. In the TLC test, the silica gel 60 F254 stationary phases were used to identify saponins with the mobile phase of chloroform : methanol : water (64: $50: 1)$ and identification of flavonoids using the mobile phase of glacial acetic acid : formic acid: water : ethyl acetate $(11: 11: 27: 100)$, both compounds showed positive reactions in all test samples. The moisture content for the orange water sample ranged from $8.149 \%-9.748 \%$. Conclusion: The highest yield value was obtained in the ethanol extract of 60\% chili orange seeds by 25,28\%. In the TLC test in the stationary phase of silica gel $60 \mathrm{~F} 254$ to identify saponins and flavonoids, all samples showed a positive reaction, with ash content of all samples in the range 2,722 - 5,442\%.
\end{abstract}

Keywords: sweet orange (Citrus amblycarpa (l)), lime fruit (Citrus aurantifolia (s.)), sambal orange (Citrus sinensis (o.)), specific parameters, non-specific parameters

\begin{abstract}
Abstrak
Pendahuluan: Buah jeruk manis (Citrus amblycarpa $(L)$ ), jeruk nipis (Citrus aurantifolia (S.)), dan jeruk sambal (Citrus sinensis $(O$.)) memiliki potensi yang sangat besar khususnya kandungan senyawa metabolit sekunder. Tujuan: Pada penelitian ini bertujuan untuk mengetahui karakteristik spesifik dan non spesifik berbagai jenis buah jeruk tersebut pada pelarut etanol 60\%. Metode: Ekstrak yang diperoleh ditentukan parameter nonspesifik dan parameter spesifik ekstraknya dari masing-masing ekstrak dari komponen buah jeruk tersebut. Hasil: Berdasarkan hasil pengamatan yang dilakukan Ekstrak etanol 60\% kulit dan biji serta air pada buah jeruk tersebut dengan nilai rendemen tertinggi diperoleh pada ekstrak etanol $60 \%$ biji jeruk sambal dengan rendemen yang dihasilkan sebesar $25,28 \%$. Seluruh sampel mengandung senyawa fenolik dan flavonoid pada uji tabung. Pada uji KLT fase diam silica gel $60 \mathrm{~F}_{254}$ untuk identifikasi saponin dengan fase gerak kloroform : metanol : air $(64: 50: 1)$ dan identifikasi flavonoid menggunakan fase gerak asam asetat glasial : asam formiat : air : etil asetat $(11: 11: 27: 100)$ pada kedua senyawa tersebut menunjukkan reaksi positif pada seluruh sampel uji. Kadar air untuk sampel air jeruk berkisar antara 8,149\% - 9,748\%. Kesimpulan: Nilai rendemen tertinggi diperoleh pada ekstrak etanol $60 \%$ biji jeruk sambal sebesar 25,28\%.
\end{abstract}


Pada uji KLT fase diam silica gel 60 F 254 untuk identifikasi saponin dan flavonoid seluruh sampel menunjukkan reaksi positif. Serta kadar abu seluruh sampel pada rentang 2,722 - 5,442\%.

Kata kunci: buah jeruk manis (Citrus amblycarpa (l)), buah jeruk nipis (Citrus aurantifolia (s.)), buah jeruk sambal (Citrus sinensis (o.)), parameter spesifik, parameter non spesifik

\section{PENDAHULUAN}

Perkembangan penggunaan obat-obatan herbal saat ini sangat signifikan. Salah satu alasan dikarenakan memiliki toksisitas yang sangat rendah. Saat ini badan kesehatan dunia (WHO) merekomendasikan dan mendorong penggunaan ramuan tradisional atau obat karena memiliki sumber bahan baku yang besar dan mudah tersedia. Tumbuhan memiliki sifat kandungan yang berbeda tergantung kepada masa tanam, waktu panen, sehingga memiliki aktivitas terapi yang bervariasi sesuai dengan spesies, lokasi geografis dan proses panen (World Health Organization, 1998). Proses identifikasi herbal yang tidak tepat, keberadaan mikroorganisme pada bahan, serta residu pestisida akibat proses pembersihan yang tidak tepat dapat menyebabkan efek samping. Oleh sebab itu, perlu dilakukan standarisasi obat herbal baik simplisia, ekstrak maupun sudah dalam bentuk sediaan. Menurut WHO, secara makroskopis dan deskripsi mikroskopis dari suatu tanaman obat merupakan gambaran kebenaran identitas suatu spesies dan dapat dijadikan sebagai landasan pengujian yang lain (World Health Organization, 1998; Apraj dkk., 2011).

Buah jeruk dalam hal ini jeruk manis (Citrus sinensis $(O$.$) ), jeruk nipis (Citrus aurantifolia (S)$.$) dan$ jeruk sambal (Citrus amblycarpa $(L)$ ) di Kalimantan Barat merupakan salah satu unggulan tanaman yang jumlahnya melimpah di masyarakat. Berdasarkan data dari Kementerian Pertanian produksi jeruk di Indonesia pada rentang tahun 1980 - 2015 meningkat secara signifikan dengan peningkatan $9,94 \%$ per tahun. Perkembangan itu terjadi dapat dilihat pada tahun 1980 total produksi jeruk di Indonesia 311.014 ton. Sedangkan pada tahun 2015 sudah menjadi 1,86 juta ton (Pusat Data dan Sistem Informasi Pertanian, 2015). Berdasarkan data dari dinas pertanian tahun 2018 tentang tanaman biofarmaka. Tanaman jeruk bukan merupakan produk tersebut meskipun Kalimantan Barat merupakan salah satu sentra tanaman jeruk namun jeruk hanya masih sebatas konsumsi biasa dan belum masuk pada bahan biofarmaka. Jeruk sendiri memiliki kandungan metabolit sekunder yang memiliki aktivitas berbagai macam indikasi penyakit.
C. aurantifolia mengandung zat fitokimia aktif sebagai berikut: (1) flavonoid termasuk apigenin, hesperetin, kaempferol, nobiletin, quercetin, dan rutin, (2) flavones, (3) flavanon dan naringenin, (4) triterpenoid, dan (5) limonoid (Poulose dkk., 2005). Penelitian lain yang dilakukan Lota mengungkapkan setidaknya 62 senyawa volatil dalam minyak kulit buah dan 59 dalam minyak daun dari beberapa spesies jeruk nipis (Lota dkk., 2002). Adapun kandungan fitokimia dan vitamin dari lima varietas spesies jeruk; $C$. sinensis, C. reticulata, C. limonum, C. aurantifolia, dan $C$. grandis, diantaranya senyawa bioaktif dalam $100 \mathrm{~g}$ jeruk terdiri dari alkaloid $(0,4 \mathrm{mg})$, flavonoid $(0,6 \mathrm{mg})$, tanin $(0,04 \mathrm{mg})$, riboflavin $(0,1 \mathrm{mg})$, tiamin $(0,2 \mathrm{mg})$, fenol $(0,4 \mathrm{mg})$, niasin $(0,5 \mathrm{mg})$, dan asam askorbat (62 mg). Selain itu, buah jeruk ini mengandung protein kasar (18\%), serat kasar (8\%), karbohidrat (78\%), kelembaban (6\%), lemak mentah (1\%), abu (8\%), dan kandungan energi makanan adalah (363 g/kal) buah segar (Narang and Jiraungkoorskul, 2016).

Penggunaan sebagai bahan obat tradisional atau sifat fitokimia dari $C$. aurantifolia dari beberapa tinjauan literatur dapat digunakan sebagai antibakteri, antidiabetik, antijamur, antihipertensi, antiinflamasi, aktivitas anti-lipidemia, antioksidan, anti-parasit, dan antiplatelet. Fungsi lainnya dapat digunakan untuk pengobatan penyakit kardiovaskular, hati, osteoporosis, dan urolitiasis dan bertindak sebagai promotor kesuburan. Selain itu, dapat digunakan untuk aktivitas insektisida (Narang and Jiraungkoorskul, 2016).

Citrus sinensis $(O$.) (L. Osbeck) atau jeruk manis berasal dari Asia Tenggara, karena terbukti memiliki vitamin $\mathrm{C}$ yang sangat tinggi, sehingga dapat dijadikan sebagai sumber antioksidan alami. Kandungan metabolit penting penting pada jeruk ini seperti narirutin $17,33 \mathrm{mg} / \mathrm{g}$ limonoid $398,30 \mathrm{mg} / \mathrm{g}$, synephrine $2,81 \mathrm{mg} / \mathrm{g}$, Hesperidin 191,53 mg/g, Nobiletin 3,00 mg/g, Tangeretin $0,26 \mathrm{mg} / \mathrm{g}$ (Sun dkk., 2013) Selain itu pada jeruk terdapat kandungan polifenol, pektin, dan folasin, kalsium, kalium, tiamin, niasin, dan magnesium. Kandungan tersebut secara biologis dapat mencegah arteriosklerosis, kanker, batu ginjal, bisul perut dan pengurangan kadar kolesterol 
darah manusia dan darah tinggi yang meningkatkan kesehatan manusia. Jeruk memiliki manfaat yang sangat banyak dan buah dapat diperoleh hampir sepanjang tahun serta harga buahnya relatif. (Etebu \& Nwauzoma, 2014).

Skrining fitokimia juga membuktikan adanya kandungan glikosida pada ekstrak etanol $70 \%$ daun $C$. amblycarpa, dimana diduga senyawa glikosida yang terdapat pada tanaman $C$. amblycarpa merupakan glikosida flavonoid. Senyawa glikosida flavonoid yang terdapat dalam jumlah besar pada tanaman citrus yaitu neohesperidin, naringin, neoeriocitrin, dan ponsirin yang mana senyawa ini memiliki peran menimbulkan rasa pahit pada jeruk. Senyawa glikosida flavonoid memiliki sifat farmakokinetik yaitu kecenderungan membentuk ikatan dengan protein plasma yang rendah sehingga konsentrasi senyawa dalam darah apabila dikonsumsi dapat bertahan lebih lama dimana sifat farmakokinetik ini merupakan sifat yang diinginkan dalam suatu obat. Senyawa glikosida flavonoid yang terdapat pada tanaman Citrus memiliki berbagai aktivitas farmakologi seperti antioksidan, antikanker dan antitumor, hepatoprotektif, antiinlamasi, antidiabetes, antiviral, antibakteri dan antifungal (Putra dkk., 2018; Wang dkk., 2017; Xiao dkk., 2016).

Menurut penelitian yang dilakukan Truong pada tahun 2018 menunjukkan bahwa perbedaan pelarut dalam proses ekstrasi akan memberikan perbedaan konsentrasi kandungan metabolit sekunder yang dihasilkan (Truong dkk., 2019).

Berdasarkan acuan di atas peneliti bermaksud untuk penelitian karakteristik spesifik dan non spesifik berbagai jenis buah jeruk tersebut pada pelarut etanol $60 \%$ dari buah jeruk baik biji, air dan kulitnya.

\section{BAHAN DAN METODE}

\section{Bahan}

Bahan-bahan yang digunakan adalah buah jeruk sambal (Citrus amblycarpa (L)), jeruk manis (Citrus sinensis (O.)), dan jeruk nipis (Citrus aurantifolia (S.)), larutan aluminium, asam sulfat pekat (Merck), methanol (Merck), asam asetat glasial (Merck), etanol $96 \%$ teknis, larutan $\mathrm{FeCl}_{3} 1 \%$, indikator fenolftalein, kloroform beramonia $2 \mathrm{~N}$ serbuk $\mathrm{Mg}, \mathrm{H}_{2} \mathrm{SO}_{4}$ pekat, $\mathrm{HCl}$ pekat, pereaksi Mayer, perekasi Dragendorff, DMSO $15 \%$, toluena (Merck), etil asetat (Merck), metanol (Merck), larutan gelatin 0,5\%, akuades, asam asetat, nheksan (Merck), kloroform, sitroborat, anisaldehid asam sulfat, dietilamin, pereaksi Liebermann-Burchad, asam formiat, $\mathrm{FeCl}_{3}$, plat kromatografi lapis tipis (Silica Gel F 254 Merck).

Alat

Peralatan yang digunakan adalah alkoholmeter (Amarell), lemari oven (Memmert BeschickungLoading Model 100-800), hot plate (Thermolyne Hot Plate RC 2240), kaca arloji, maserator (berbahan kaca), krus proselen, mortir, jarum ose, desikator, sendok tanduk, timbangan analitik (Precisa tipe XB 4200C dan BEL tipe M254Ai), plat silika gel $\mathrm{F}_{254}$ dan bejana KLT, rotary evaporator (Rotavapor II BUCHI), lampu UV254 nm dan UV366 nm.

Metode

Determinasi tanaman

Identitas dan kebenaran suatu tanaman dapat diketahui melalui determinasi. Determinasi dapat menggunakan tanaman utuh, maupun bagian dari tanaman. Pada penelitian ini determinasi menggunakan buah jeruk tersebut sebagai media. Adapun proses determinasi tersebut dilakukan di Jurusan Biologi Fakultas MIPA Universitas Tanjungpura Pontianak.

\section{Preparasi bahan}

Sebelum dilakukan ekstraksi sampel, maka terlebih dahulu dilakukan preparasi bahan tersebut. Sampel tersebut diantaranya adalah jeruk sambal, jeruk manis, dan jeruk nipis meliputi bagian kulit, biji, dan sari buah jeruk. Pelarut yang digunakan dalam proses ekstraksi menggunakan etanol 60\%. Ketiga sampel dicuci dengan air mengalir kemudian dikeringkan. Sampel dipisahkan bagian sari, biji, dan kulitnya. Kulit jeruk nipis (KJN), kulit jeruk sambal (KJS), biji jeruk nipis (BJN) dan biji jeruk sambal (BJS) dipisahkan dari masing masing komponen, kemudian dikeringkan dalam oven bersuhu $40^{\circ} \mathrm{C}$. Simplisia yang kering ditandai dengan diremas untuk kulit akan hancur, sedangkan untuk biji sudah terpisah dari masingmasing biji. Kulit jeruk tiap sampel yang telah kering dibuat serbuk dengan diblender agar menjadi serbuk dan kemudian dilewatkan pada ayakan mesh 60. Hasil preparasi sampel dari buah jeruk tersebut yang berupa air jeruk nipis (AJN), air jeruk sambal (AJS) dan air jeruk manis (AJM) dilakukan freeze drying.

\section{Ekstraksi kulit jeruk, air jeruk, dan biji jeruk}

Simplisia kulit jeruk dan biji jeruk yang sudah diserbukkan ditimbang dan maserasi dalam alat maserator dan ditambah dengan pelarut etanol $60 \%$ sambil diaduk dengan batang pengaduk. Maserasi dilakukan sebanyak 3 kali replikasi dengan penggantian pelarut dilakukan setiap 72 jam dengan pelarut yang sama pada saat maserasi pertama. Hasil 
maserat 3 kali replikasi dikumpulkan dan disaring menggunakan corong buchner yang telah diberi kertas saring Whatman no 1. Maserat yang telah diperoleh disaring, kemudian dievaporasi dengan hingga terbentuk masa yang pekat. hasil dari massa tersebut dimasukkan pada desikator untuk membentuk ekstrak, Proses pengeringan berhenti ketika massa yang terbentuk konstan setelah dilakukan penimbangan.

\section{Pengujian skrining fitokimia ekstrak}

Proses skrining fitokimia ekstrak dilakukan dengan 2 cara yaitu pertama dengan menggunakan kromatografi lapis tipis (KLT) yang dilakukan untuk melihat parameter spesifik dari ekstrak tersebut. Metode kedua metode uji tabung dan menggunakan penetapan susut pengeringan, penetapan kadar sari larut air, kadar air, kadar sari yang larut dalam etanol, kadar abu tidak larut asam, dan kadar abu total.

\section{Kromatografi lapis tipis}

Pada pengujian menggunakan kromatografi lapis tipis dilakukan beberapa orientasi terutama penggunaan pelarut sebagai fase gerak. Fase diam yang digunakan adalah silica gel $60 \mathrm{~F}_{254}$. Pengamatan bercak dilakukan pada sinar tampak (panjang gelombang 380$700 \mathrm{~nm}$ ), UV254 dan UV366. Adapun fase gerak yang digunakan pada pengujian skrining fitokimia meliputi toluene : etil asetat : dietil amina $(7: 2: 1)$ dengan pereaksi semprot : Dragendorff (uji kandungan alkaloid), etil asetat : toluene : asam formiat : air (6:3:1,5:0,5) menggunakan pereaksi semprot: $\mathrm{FeCl}_{3}$ (uji fenolik), asam asetat glasial : asam formiat : air : etil asetat : $(11: 11: 27: 100)$ dengan sitroborat digunakan sebagai pereaksi semprot (uji flavonoid), kloroform : metanol : air (64:50:1) pereaksi semprot : Liebermann-Burchard (saponin), n-heksana : etil asetat (4:1) disemprot menggunakan pereaksi LiebermannBurchard (uji steroid), dan heksana : etil asetat (93:7) pereaksi semprot : anisaldehid asam sulfat (uji terpenoid) (Kaya dkk., 2012; Fauziah, 2006; Safitri, 2016; Wagner \& Bladt, 1996; Santosa \& Haresmita, 2015).

\section{Penentuan karakteristik non spesifik ekstrak}

Penentuan karakteristik ekstrak meliputi penetapan susut pengeringan, penetapan kadar sari larut air, kadar air, kadar sari yang larut dalam etanol, kadar abu tidak larut asam, dan kadar abu total. Prosedur kerja dari penetapan parameter tersebut menggunakan aturan yang berlaku (Direktorat Jenderal Bina Kefarmasian dan Alat Kesehatan, 2008; Direktorat Pengawasan Obat Tradisional, 2000).

\section{Metode uji tabung \\ Uji alkaloid}

Sampel yang diperoleh ditambahkan pelarut dalam beberapa tetes asam sulfat $2 \mathrm{~N}$ kemudian diuji dengan pereaksi alkaloid yaitu, pereaksi Mayer (Harborne dkk., 1996).

Uji fenolik

Sejumlah $100 \mathrm{mg}$ sampel uji dilarutkan dengan $1 \mathrm{~mL}$ air pada tabung reaksi dan kemudian tambahkan 1-2 tetes besi III klorida $\left(\mathrm{FeCl}_{3}\right)$. Jika terbentuk warna biru, hijau, merah atau ungu menunjukkan keberadaan senyawa fenol (Rao, 2016).

\section{Uji flavonoid}

Pengujian flavonoid didahului dengan menambahkan magnesium $0,1 \mathrm{mg}$ dan $0,4 \mathrm{~mL}$ amil alkohol (campuran asam klorida 37\% dan etanol 95\% dengan volume yang sama) ke dalam sampel ekstrak yang diuji dan ditambahkan $4 \mathrm{~mL}$ alkohol kemudian campuran dikocok. Senyawa mengandung flavonoid ditunjukkan dengan perubahan warna menjadi merah, kuning atau jingga pada lapisan amil alkohol. (Harborne dkk., 1996).

\section{Saponin}

Sampel ekstrak dilarutkan dengan air hingga volume $20 \mathrm{~mL}$ kemudian dikocok dengan roller mixer selama 5 menit dan apabila terbentuk sabun setinggi 2 $\mathrm{cm}$ pada lapisan atas menunjukkan keberadaan saponin (Mir dkk., 2016).

\section{Uji steroid}

Sampel ekstrak dilarutkan ke dalam air sehingga membentuk larutan siap untuk di uji. Larutan tersebut diambil sebanyak $2 \mathrm{~mL}$ diuapkan, residu yang diperoleh dilarutkan dengan $0,5 \mathrm{~mL}$ kloroform, $0,5 \mathrm{~mL}$ ditambahkan asam asetat anhidrat kemudian $2 \mathrm{~mL}$ asam sulfat $\mathrm{P}$ melalui dinding tabung. Cincin biru kehijauan akan terbentuk apabila senyawa mengandung steroid dan cincin kecoklatan atau violet menandakan adanya triterpenoid (Putra dkk., 2018). Warna biru dan hijau untuk steroid (Dwisari dkk., 2016).

\section{Uji terpenoid}

Sampel ekstrak yang sudah dilarutkan dalam air diambil sebanyak $2 \mathrm{~mL}$ selanjutnya ditambahkan reagen Liebermann-Burchad yang mengandung campuran antara $\mathrm{HCl}$ pekat dengan $\mathrm{H}_{2} \mathrm{SO}_{4}$ pekat. Perubahan warna merah jingga akan muncul jika sampel mengandung triterpenoid (Sangi dkk., 2008). 


\section{HASIL DAN PEMBAHASAN}

\section{Determiasi Tanaman}

Determinasi tanaman merupakan salah satu tahapan untuk mengetahui identitas suatu sampel adalah benar. Sampel yang digunakan dalam determinasi pada penelitian ini adalah buah dari tanaman yang diidentifikasi di laboratorim biologi, Jurusan Biologi Fakultas Matematika dan Ilmu Pengetahuan Alam (FMIPA) Universitas Tanjungpura. Buah yang diambil adalah yang berusia 8 bulan, buah tersebut diperoleh dari desa Pal Sembilan kecamatan Sungai kakap. Berdasarkan hasil determinasi menunjukkan bahwa tanaman yang digunakan termasuk dalam genus rutaceae, familia Citrus dengan spesies Citrus amblycarpa (L), Citrus aurantifolia (S.), dan Citrus sinensis (O.).

\section{Ekstraksi}

Ekstraksi yang dilakukan adalah dengan metode ekstraksi dingin yaitu maserasi. Metode ini dapat digunakan untuk bahan yang tidak tahan tehadap pemanasan, serta penggunaannya relatif sederhana, dan dapat mengekstraksi lebih banyak kandungan metabolit sekunder. Namun tidak semua terkestraksi dengan baik karena pelarut yang digunakan pada suhu kamar. (Nurhasnawati dkk., 2017) Pelarut yang digunakan merupakan pelarut polar yaitu etanol $60 \%$. Pelarut ini dapat menyari senyawa yang memiliki karakteristik polar, semi polar maupun non polar, hal ini disebabkan karena karakter pelarut universal yakni pelarut yang dapat menyari hampir seluruh metabolit sekunder. Penelitian yang dilakukan oleh Do menggunakan variasi pelarut etanol $75 \%$ dan $50 \%$ memberikan hasil rendemen lebih banyak pada konsentrasi $50 \%$ dengan rendemen $32,98 \%$ serta kandungan fenolik total sebesar 30,30 GAE/g dengan nilai yang tidak signifikan dibandingkan dengan konsentrasi 75\%. (Do dkk., 2014). Berdasarkan penelitian yang dilakukan rendemen tertinggi diperoleh pada ekstrak etanol biji jeruk sambal dengan rendemen 25,28\%. Pelarut etanol $60 \%$ memiliki kandungan air yang relatif kecil sehingga proses evaporasi atau pengeringan lebih cepat dan dapat menghindari pertumbuhan jamur/kapang pada ekstrak. Proses ekstraksi dilakukan selama 72 jam berdasarkan penelitian yang dilakukan pada rentang waktu tersebut (kisaran 3-6 hari) memberikan nilai total fenolik yang optimal. (Kelebek dkk., 2006).

Hasil ekstrak memiliki wujud berwarna kuning hingga coklat tua dengan karakteristik ekstrak kental. Hal ini menandakan bahwa senyawa-senyawa tersebut mengandung salah satu metabolit flavonoid, terutama flavanon dan kalkon berwarna kuning orange. Warna kuning kecoklatan menandakan bahwa senyawasenyawa flavonoid larut dalam ekstrak (Handayani dkk., 2005).

Ekstrak yang digunakan berjumlah 7 sampel yaitu ekstrak etanol kulit jeruk nipis (KJN), kulit jeruk sambal (KJS), biji jeruk nipis (BJN), dan biji jeruk sambal (BJS) dengan 2 diantaranya yaitu hasil freeze dry air jeruk nipis (AJN), air jeruk manis (AJM) dan air jeruk sambal (AJS). Hasil organoleptik menunjukkan bahwa ekstrak termasuk dalam kategori ekstrak kental berwarna cokelat. Hasil berat ekstrak yang diperoleh dapat dilihat pada Tabel 1. Berdasarkan data pada Tabel 1 menunjukkan bahwa rendemen yang paling banyak dari hasil proses ekstraksi adalah ekstrak etanol $60 \%$ biji jeruk sambal dengan rendemen yang dihasilkan sebesar $25,28 \%$.

Tabel 1. Berat ekstrak dan persen rendemen tiap ekstrak etanol $60 \%$ buah jeruk sambal, jeruk manis, dan jeruk nipis

\begin{tabular}{cccc}
\hline Sampel & Berat serbuk yang diekstraksi $(\mathrm{g})$ & Berat ekstrak $(\mathrm{g})$ & \%Rendemen \\
\hline KJN & 350,00 & 20,70 & 5,91 \\
KJS & 350,00 & 32,30 & 9,23 \\
BJS & 26,50 & 6,70 & 25,28 \\
BJN & 25,50 & 1,80 & 7,06 \\
AJN & 65,19 & 13,50 & 20,70 \\
AJS & 79,13 & 4,80 & 6,06 \\
AJM & 53,77 & 8,50 & 15,80 \\
\hline
\end{tabular}

\section{Skrining fitokimia dengan menggunakan KLT}

Skrining fitokimia dengan menggunakan kromatografi lapis tipis adalah salah satu identifikasi untuk melihat profil kandungan metabolit sekunder yang ada di dalam suatu sampel. Hasil Identifikasi dapat dijadikan rujukan untuk menentukan bahan spesifik yang ada di dalam ekstrak sampel tersebut.
Berdasarkan Gambar 1 dapat diketahui bahwa sebelum disemprot menggunakan penampak bercak sitroborat tidak terjadi perubahan warna pada sinar UV254 yang dapat dikatakan bahwa sebelum atau setelah disemprot dengan penampak bercak. Hasil tersebut menunjukkan bahwa flavonoid pada sinar UV254 memberikan hasil yang negatif. Sedangkan 
pada UV366 terjadi peredaman fluorosensi dan setelah penyemprotan dengan penampak bercak sitroborat terjadi fluorosensi kuning, hijau atau biru serta warnanya menjadi lebih intensif. Intensitas warna pada setiap jenis ekstrak berbeda menunjukkan bahwa konsentrasi dari flavonoid yang dihasilkan berbeda. (Wagner \& Bladt, 1996) Sitroborat digunakan sebagai pendeteksi golongan flavonoid menghasilkan warna kuning terang ketika disinar dengan UV366. Hal in terjadi karena kromatogram ekstrak etanol jeruk sesudah disemprot sitroborat yang memiliki struktur dasar flavonol yang mengandung 3-OH bebas dengan atau tanpa 5-OH bebas serta mengandung gugus ortodihidroksi. Ekstrak menunjukkan kemungkinan mengandung senyawa flavonoid berstruktur dasar flavonol dengan gugus orto-dihidroksi (Challice, 1984).

Pada Gambar 3 menunjukkan bahwa seluruh ekstrak buah jeruk mengandung saponin yang tampak pada kromatogram pada sinar UV366 tampak bercak berwarna coklat kehitaman dan intensitas bercak semakin jelas setelah disemprot dengan pereaksi Liebermann-Burchad baik disinar tampak, UV254 dan UV366. Adapun nilai Rf dari data kromatogram adalah 0,75 , perbedaan intensitas penampakan bercak pada kromatogram tersebut dapat disebabkan karena ada perbedaan konsentrasi saponin di dalam ekstrak.

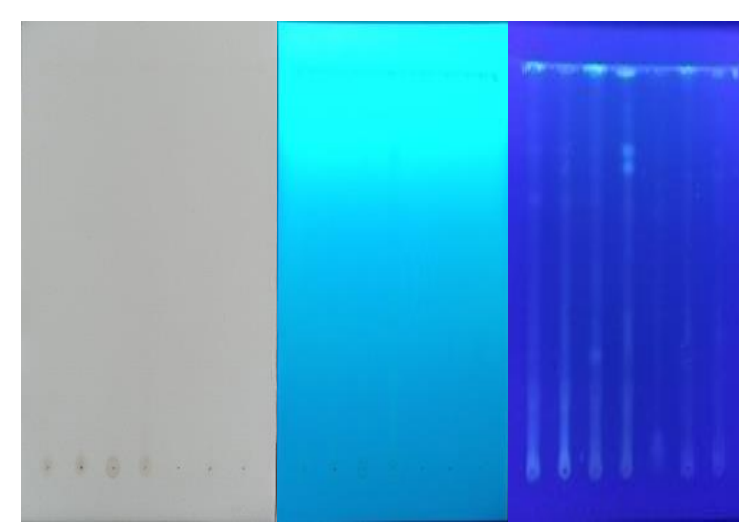

(a) (b)

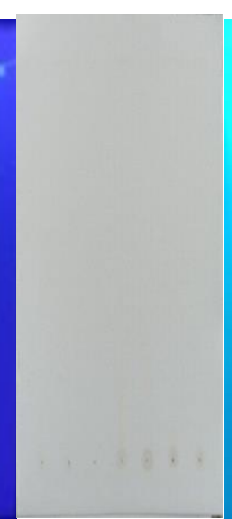

(d)

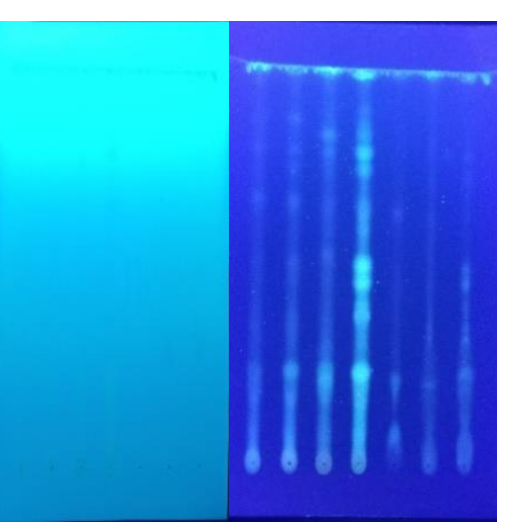

(e) (f)

Gambar 1. Hasil skrining senyawa flavonoid pada ekstrak etanol 60\% kulit, biji buah jeruk serta air jeruk menggunakan fase diam silica gel $60 \mathrm{~F}_{254}$ dan fase gerak asam asetat glasial : asam formiat : air : etil asetat (11:11:27:100) dengan perekasi penampak bercak sitroborat; (a) sinar tampak (sebelum semprot), (b) UV254 (sebelum semprot), (c) UV366 (sebelum semprot), (d) sinar tampak (setelah semprot), (e) UV254 (setelah semprot),

(f) UV366 (setelah semprot)

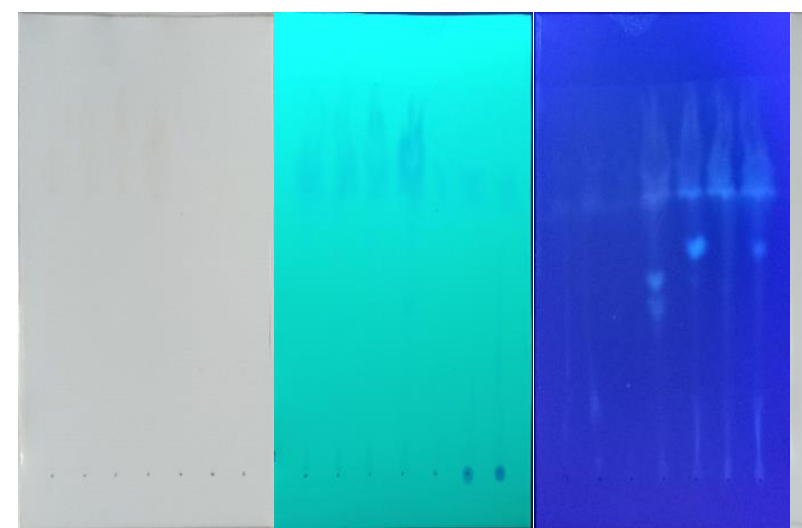

(a) (b)

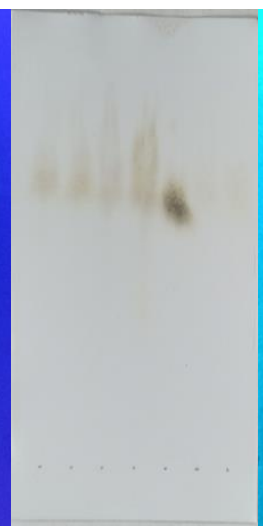

(d)

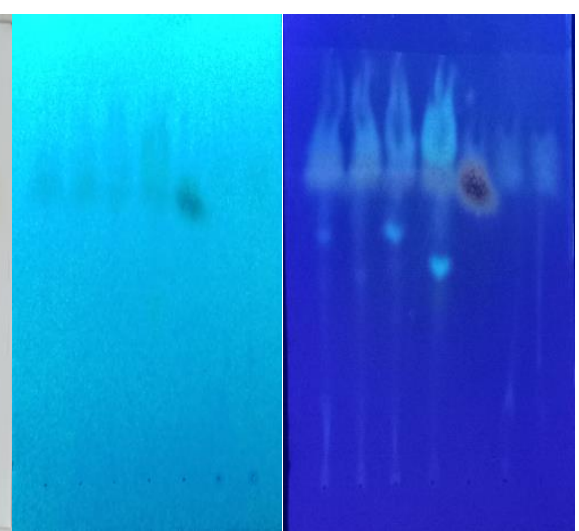

(e) (f)

Gambar 2. Hasil skrining senyawa saponin pada ekstrak etanol 60\% kulit, biji buah jeruk serta air jeruk menggunakan fase diam silica gel $60 \mathrm{~F}_{254}$ dan fase gerak kloroform : methanol : air (64: $\left.50: 1\right)$ dengan pereaksi penampak bercak Liebermann-Burchad; (a) sinar tampak (sebelum semprot), (b) UV254 (sebelum semprot), (c) UV366 (sebelum semprot), (d) Sinar tampak (setelah semprot), (e) UV254 (setelah semprot), (f) UV366 (setelah semprot) 
Sampel yang diuji dengan KLT (Gambar 3) menunjukkan hasil yang positif terpenoid pada ekstrak biji jeruk sambal, ekstrak kulit jeruk nipis dan ekstrak air jeruk nipis yang dapat dilihat pada sinar UV366 dengan kromatogram berwarna hijau. Namun tidak tampak pada UV254 dan sinar tampak. Setelah dilakukan penyemprotan menggunakan penampak bercak Anisaldehida-asam sulfat intensitas bercak pada UV366 menurun namun pada sinar tampak berwarna merah keunguan, hal ini disebabkan karena adanya reaksi antara sampel dan pereaksi menbentuk kompleks pada daerah sinar tampak (Karthika dkk., 2014). Golongan senyawa terpenoid dan fenol bereaksi dengan Anisaldehida-asam sulfat memberikan warna ungu, biru, merah, kelabu atau hijau tergantung jenis

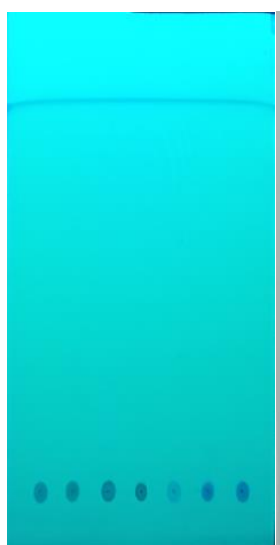

(a)

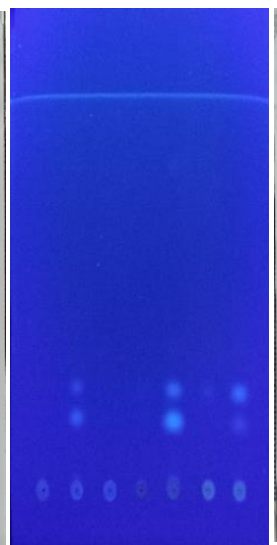

(c) (b)

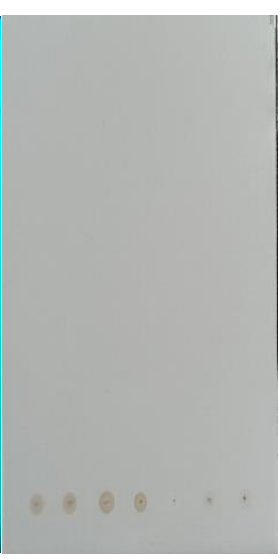

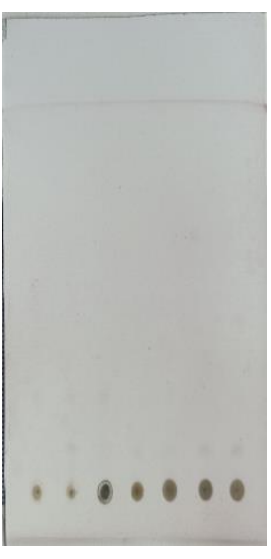

(d)

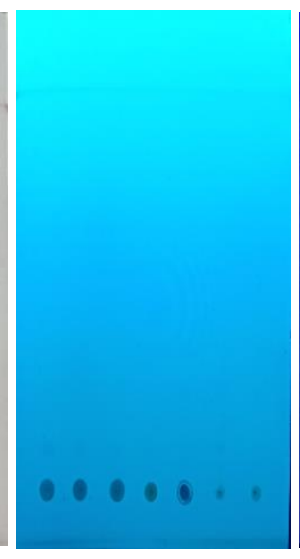

(e)

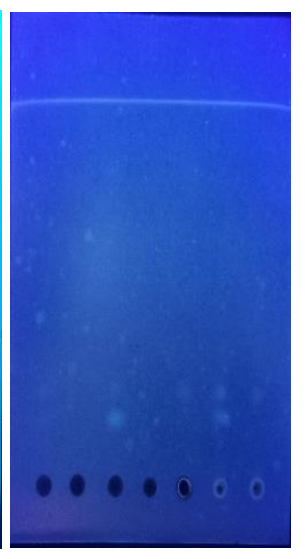

(f)

Gambar 3. Hasil Skrining senyawa terpenoid pada ekstrak etanol 60\% kulit, biji buah jeruk serta air jeruk menggunakan fase diam silica gel $60 \mathrm{~F}_{254}$ dan fase gerak heksana : etil asetat (93:7) dengan perekasi penampak bercak Anisaldehida-asam sulfat; (a) sinar tampak (sebelum semprot) (b) UV254 (sebelum semprot), (c) UV366 (sebelum semprot), (d) sinar tampak (setelah semprot), (e) UV254 (setelah semprot), (f) UV366 (setelah semprot)

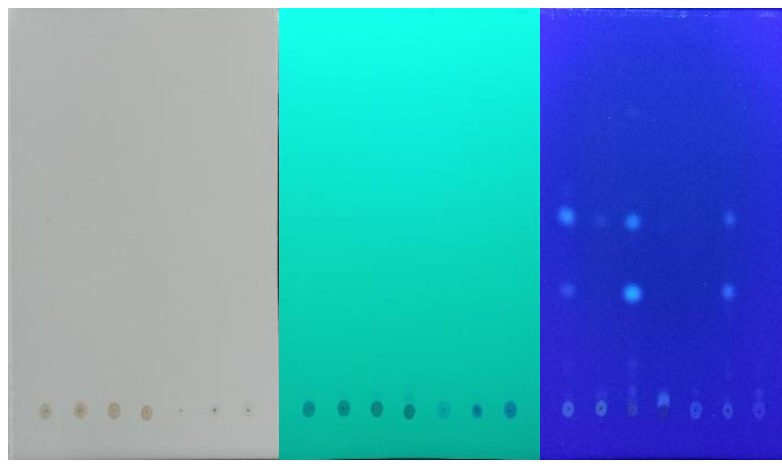

(a) (b)

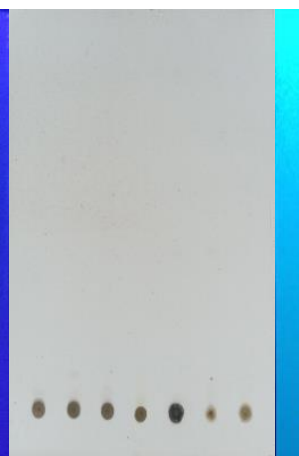

(d)

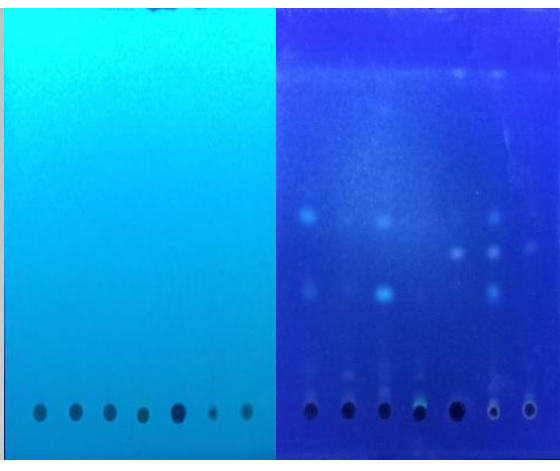

(e) (f)

Gambar 4. Hasil skrining senyawa steroid pada ekstrak etanol 60\% kulit, biji buah jeruk serta air jeruk menggunakan fase diam silica gel $60 \mathrm{~F}_{254}$ dan fase gerak heksana: etil asetat (4:1) dengan perekasi penampak bercak

Liebermann-Burchad; (a) sinar tampak (sebelum semprot), (b) UV254 (sebelum semprot), (c) UV366 (sebelum semprot), (d) sinar tampak (setelah semprot), (e) UV254 (setelah semprot), (f) UV366 (setelah semprot) 
Berdasarkan pengamatan pada Gambar 5 tampak bahwa hasil kromatogram sebelum direaksikan dengan penampak bercak menggunakan UV366 sebanyak 8 titik dengan nilai rf 0,$56 ; 0,62 ; 0,81$; dan 0,94 berwarna hijau dan biru. kromatogram tersebut muncul pada sampel ekstrak biji jeruk nipis, ekstrak kulit jeruk sambal, ekstrak air jeruk manis, ekstrak air jeruk sambal. Setelah dilakukan penyemprotan dengan pereaksi Dragendorff pola kromatogram yang muncul intensitasnya menurun pada UV366 akibat peredaman pereaksi pada senyawa, reaksi tersebut muncul karena pergeseran panjang akibat derivatisasi pereaksi dan sampel ke arah sinar tampak (Farnsworth, 1966). Namun, dilihat setelah semprot dengan pereaksi Dragendorff di sinar tampak berwarna jingga yang menunjukkan positif alkaloid. Faktor lain yang dapat mempengaruhi adalah katena elektron pasangan bebas $\mathrm{N}_{4}$ mungkin memiliki kadar yang sedikit dalam sampel sehingga proses adsorpsi isomer dan adanya karbonil amida pada lingkungan yang sama dengan isomer. Peristiwa tersebut kemungkinan menyebabkan perbedaan dalam adsorpsi akibat dari ketersediaan oksigen piran yang bervariasi atau gugus karbometoksi (Phillipson \& Hemingway, 1975). Perbedaan pola kromatogram dari sampel dapat disebabkan oleh jenis alkaloidnya (Berdasarkan pengamatan pada gambar 6 tampak bahwa hasil kromatogram sebelum direaksikan dengan penampak bercak menggunakan UV366 sebanyak 8 titik dengan nilai rf 0,$56 ; 0,62 ; 0,81$; dan 0,94 berwarna hijau dan biru. kromatogram tersebut muncul pada sampel ekstrak biji jeruk nipis, ekstrak kulit jeruk sambal, ekstrak air jeruk manis, ekstrak air jeruk sambal. Setelah dilakukan penyemprotan dengan pereaksi Dragendorff pola kromatogram yang muncul intensitasnya menurun pada UV366 akibat peredaman pereaksi pada senyawa, reaksi tersebut muncul karena pergeseran panjang akibat derivatisasi pereaksi dan sampel ke arah sinar tampak. (Farnworth, 1966) Namun, dilihat setelah semprot dengan pereaksi Dragendorff di sinar tampak berwarna jingga yang menunjukkan positif alkaloid. Faktor lain yang dapat mempengaruhi adalah karena elektron pasangan bebas $\mathrm{N}_{4}$ mungkin memiliki kadar yang sedikit dalam sampel sehingga proses adsorpsi isomer dan adanya karbonil amida pada lingkungan yang sama dengan isomer. Peristiwa tersebut kemungkinan menyebabkan perbedaan dalam adsorpsi akibat dari ketersediaan oksigen piran yang bervariasi atau gugus karbometoksi (Phillipson and Hemingway, 1975). Perbedaan pola kromatogram dari sampel dapat disebabkan oleh jenis alkaloidnya (Pamungkas \& Murrukmihadi, 2015; Wagner \& Bladt, 1996; Wagner \& Bladt, 1996).

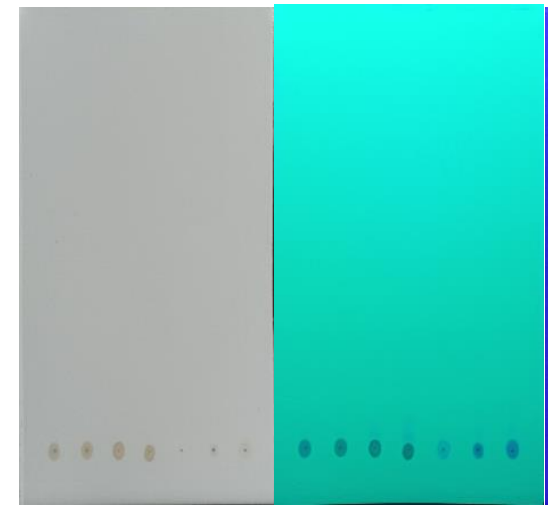

(a)

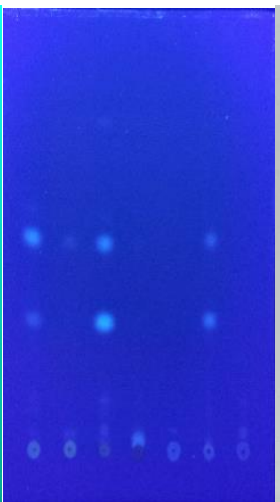

(c)

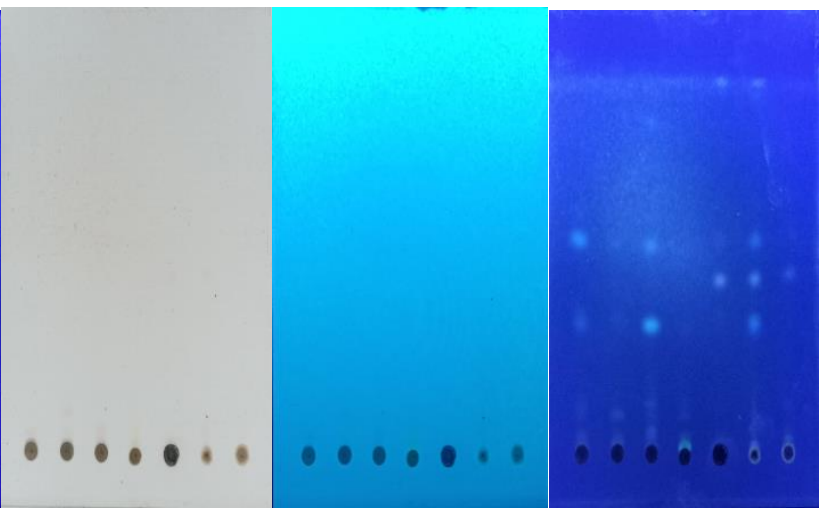

(d) (e) (f)

Gambar 5. Hasil skrining senyawa alkaloid pada ekstrak etanol 60\% kulit, biji buah jeruk serta air jeruk menggunakan fase diam silica gel 60 F254 dan fase gerak toluene : etil asetat : dietil amina (7:2:1) dengan pereaksi penampak bercak Dragendorff; (a) sinar tampak (sebelum semprot), (b) UV254 (sebelum semprot), (c) UV366 (sebelum semprot), (d) sinar tampak (setelah semprot), (e) UV254 (setelah semprot), (f) UV366 (setelah semprot)

Pada Gambar 6 terlihat oleh hasil kromatogram dengan UV366 untuk senyawa fenolik pada semua sampel tampak nyata dengan membentuk spot yang berbeda setiap senyawa, hal ini disebabkan bahwa jenis senyawa fenolik setiap sampel uji berbeda. Namun setelah disemprot dengan $\mathrm{FeCl}_{3}$ Pola kromatogram tersebut intensitasnya menurun atau terbentuk warna ungu. Perubahan tersebut disebabkan oleh senyawa fenolik memiliki ikatan rangkap terkonjugasi pada saat belum disemprot dengan $\mathrm{FeCl}_{3}$, ketika setelah 
disemprot ikatan tersebut akan lepas dan akan berikatan dengan ion $\mathrm{Fe}^{3+}$ yang akan membentuk kompleks dan mengakibatkan pergeseran panjang gelombang (Al-Maliki, 2011). Sedangkan pada sinar tampak setelah semprot berwarna hijau tua kehitaman) (Santosa \& Haresmita 2015). Perubahan warna hijau, merah, coklat, ungu, biru, atau hitam yang kuat akan muncul ketika ekstrak yang diuji mengandung senyawa fenol setelah direaksikan dengan penampak bercak $\mathrm{FeCl}_{3}$. Setelah disemprot $\mathrm{FeCl}_{3}$, pada plat KLT Gambar 6 tampak terjadi perubahan warna yaitu hijau kecoklatan lebih pudar dan biru keunguan menjadi lebih intensif. Hal ini dapat menunjukkan kemungkinan bahwa spot yang muncul tersebut mengandung senyawa fenol (Harborne dkk., 1996).

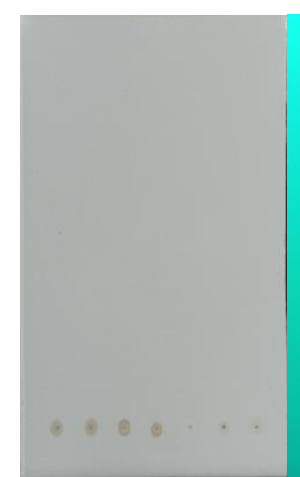

(a)

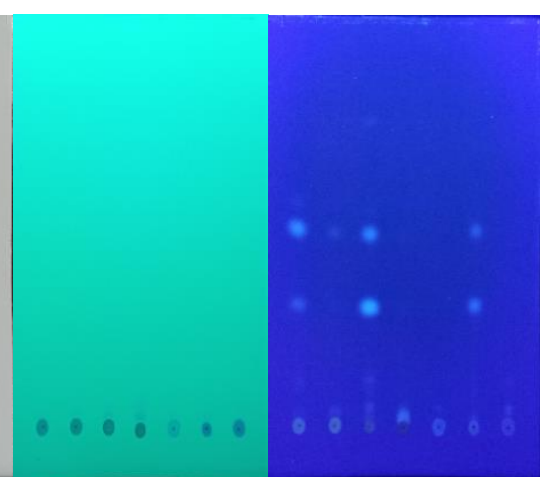

(b) (c)

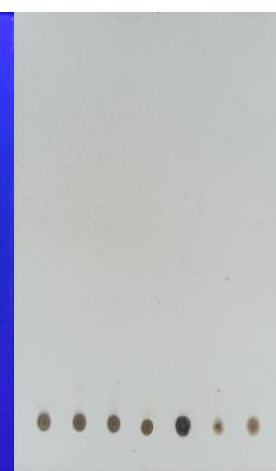

(d)

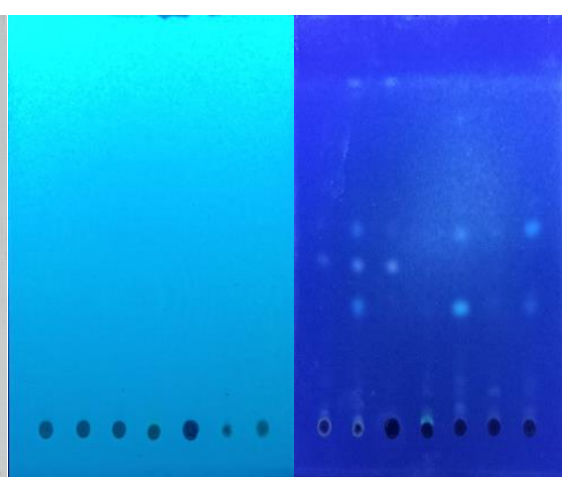

(e) (f)

Gambar 6. Hasil skrining senyawa fenol pada ekstrak etanol $60 \%$ kulit, biji buah jeruk serta air jeruk di elusi menggunakan fase diam silica gel $60 \mathrm{~F}_{254}$ dan fase gerak etil asetat : toluene : asam formiat : air $(6: 3: 1,5: 0,5)$ dengan pereaksi penampak bercak $\mathrm{FeCl}_{3}$; (a) sinar tampak (sebelum semprot), (b) UV254 (sebelum semprot), (c) UV366 (sebelum semprot), (d) sinar tampak (setelah semprot), (e) UV254 (setelah semprot), (f) UV366 (setelah semprot)

\section{Skrining fitokimia}

Skrining Fitokimia merupakan salah satu bentuk standarisasi suatu ekstrak untuk melihat kandungan metabolit yang terdapat dalam suatu tanaman. Skrining ini menjadi dasar untuk melanjutkan pengujian analisis farmakologi, toksikologi serta farmasetika.

Berdasarkan data pada Tabel 2 diketahui bahwa seluruh sampel mengandung senyawa fenolik, hal ini ditunjukkan dengan perubahan warna sampel dari hijau menjadi biru kehitaman. Seluruh sampel juga menunjukkan mengandung flavonoid yang ditandai dengan perubahan warna sampel menjadi merah pekat. Pada uji flavonoid menggunakan pereaksi magnesium. Pereaksi ini dapat digunakan karena dapat mereduksi terutama senyawa flavonoid dalam suasana asam dengan penambahan $\mathrm{HCl}$ (Sopianti, 2018).

Tabel 2. Hasil identifikasi Golongan senyawa ekstrak etanol $60 \%$ pada komponen buah C. amblycarpa (L.), C. sinensis (O.), dan C. aurantifolia (S.)

\begin{tabular}{|c|c|c|c|c|c|c|c|}
\hline $\begin{array}{l}\text { Jenis } \\
\text { metabolit } \\
\text { sekunder }\end{array}$ & Ekstrak & Fase gerak & $\begin{array}{l}\text { Pereaksi } \\
\text { semprot }\end{array}$ & $\begin{array}{l}\text { Deteksi } \\
\text { setelah } \\
\text { semprot } \\
\text { UV } 254\end{array}$ & $\begin{array}{l}\text { Deteksi } \\
\text { setelah } \\
\text { semprot } \\
\text { UV366 }\end{array}$ & $\begin{array}{l}\text { Warna } \\
\text { bercak }\end{array}$ & Hasil \\
\hline \multirow[t]{7}{*}{ Flavonoid } & BJS & \multirow{7}{*}{$\begin{array}{l}\text { Asam } \text { asetat } \\
\text { glasial : Asam } \\
\text { formiat : Air : Etil } \\
\text { asetat } \\
(11: 11: 27: 100)\end{array}$} & \multirow[t]{7}{*}{ Sitroborat } & Peredaman & Berwarna & Kuning & + \\
\hline & BJN & & & Peredaman & Berwarna & Kuning & + \\
\hline & KJN & & & Peredaman & Berwarna & Kuning & + \\
\hline & KJS & & & Peredaman & Berwarna & Kuning & + \\
\hline & AJM & & & Peredaman & Berwarna & Kuning & + \\
\hline & AJN & & & Peredaman & Berwarna & Kuning & + \\
\hline & AJS & & & Peredaman & Berwarna & Kuning & + \\
\hline \multirow[t]{3}{*}{ Saponin } & BJS & \multirow{3}{*}{$\begin{array}{l}\text { Kloroform } \\
\text { Metanol } \\
(64: 50: 1)\end{array}$} & \multirow{3}{*}{$\begin{array}{l}\text { Liebermann- } \\
\text { Burchard }\end{array}$} & Peredaman & Berwarna & $\begin{array}{l}\text { Coklat } \\
\text { Kehitaman }\end{array}$ & + \\
\hline & BJN & & & Peredaman & Berwarna & $\begin{array}{l}\text { Coklat } \\
\text { Kehitaman }\end{array}$ & + \\
\hline & KJN & & & Peredaman & Berwarna & Coklat & + \\
\hline
\end{tabular}




\begin{tabular}{|c|c|c|c|c|c|c|c|}
\hline & & & & & & Kehitaman & \\
\hline & KJS & & & Peredaman & Berwarna & $\begin{array}{l}\text { Coklat } \\
\text { Kehitaman }\end{array}$ & + \\
\hline & AJM & & & Peredaman & Berwarna & Coklat & + \\
\hline & AJN & & & Peredaman & Berwarna & $\begin{array}{l}\text { Kehitaman } \\
\text { Coklat }\end{array}$ & + \\
\hline & & & & & & Kehitaman & \\
\hline & AJS & & & Peredaman & Berwarna & $\begin{array}{l}\text { Coklat } \\
\text { Kehitaman }\end{array}$ & + \\
\hline Terpenoid & BJS & Heksana : Etil & Anisaldehid- & Peredaman & Berwarna & Hijau & + \\
\hline & BJN & asetat (93:7) & asam sulfat & Peredaman & Peredaman & - & - \\
\hline & KJN & & & Peredaman & Berwarna & Hijau & + \\
\hline & KJS & & & Peredaman & Peredaman & - & - \\
\hline & AJM & & & Peredaman & Peredaman & - & - \\
\hline & AJN & & & Peredaman & Berwarna & Hijau & + \\
\hline & AJS & & & Peredaman & Peredaman & - & - \\
\hline Steroid & BJS & $\begin{array}{l}\text { Heksana : } \\
\text { asetat }(4: 1)\end{array}$ & $\begin{array}{l}\text { Liebermann- } \\
\text { Burchad }\end{array}$ & Peredaman & Berwarna & $\begin{array}{l}\text { Biru } \\
\text { Kehijauan }\end{array}$ & + \\
\hline & $\mathrm{BJN}$ & & & Peredaman & Peredaman & - & - \\
\hline & KJN & & & Peredaman & Berwarna & $\begin{array}{l}\text { Biru } \\
\text { Kehijauan }\end{array}$ & + \\
\hline & KJS & & & Peredaman & Peredaman & - & - \\
\hline & AJM & & & Peredaman & Berwarna & $\begin{array}{l}\text { Biru } \\
\text { Kehijauan }\end{array}$ & + \\
\hline & AJN & & & Peredaman & Berwarna & $\begin{array}{l}\text { Biru } \\
\text { Kehijauan }\end{array}$ & + \\
\hline & AJS & & & Peredaman & Berwarna & $\begin{array}{l}\text { Biru } \\
\text { Kehijauan }\end{array}$ & + \\
\hline Alkaloid & BJS & Toluena & Dragendorff & Peredaman & Peredaman & - & - \\
\hline & BJN & asetat : Dietil & & Peredaman & Berwarna & Hijau & + \\
\hline & KJN & amina $(7: 2: 1)$ & & Peredaman & Peredaman & - & - \\
\hline & KJS & & & Peredaman & Berwarna & Biru & + \\
\hline & AJM & & & Peredaman & Berwarna & Hijau & + \\
\hline & AJN & & & Peredaman & Peredaman & - & - \\
\hline & AJS & & & Peredaman & Berwarna & Hijau & + \\
\hline Fenolik & BJS & Etil asetat & $\mathrm{FeCl}_{3}$ & Peredaman & Berwarna & Biru & + \\
\hline & BJN & $\begin{array}{l}\text { Toluena : Asam } \\
\text { formiat : Air (6: } 3 \text { : } \\
\text { 1,5: } 0,5)\end{array}$ & & Peredaman & Berwarna & $\begin{array}{l}\text { Keunguan } \\
\text { Biru } \\
\text { Keunguan }\end{array}$ & + \\
\hline & KJN & & & Peredaman & Berwarna & Hijau & + \\
\hline & KJS & & & Peredaman & Berwarna & $\begin{array}{l}\text { Biru } \\
\text { Keunguan }\end{array}$ & + \\
\hline & AJM & & & Peredaman & Berwarna & $\begin{array}{l}\text { Biru } \\
\text { Keunguan }\end{array}$ & + \\
\hline & AJN & & & Peredaman & Berwarna & $\begin{array}{l}\text { Biru } \\
\text { Keunguan }\end{array}$ & + \\
\hline & AJS & & & Peredaman & Berwarna & $\begin{array}{l}\text { Biru } \\
\text { Keunguan }\end{array}$ & + \\
\hline
\end{tabular}

Keterangan: BJS: biji jeruk sambal; BJN: biji jeruk nipis; KJN: Kulit jeruk nipis; KJS: kulit jeruk sambal; AJM: air jeruk manis; AJN: air jenuk nipis; AJS: air jeruk sambal; fase diam yang digunakan adalah Silica Gel $60 \mathrm{~F}_{254}$

Kandungan alkaloid didapat pada ekstrak etanol kulit dan biji jeruk namun tidak ditemukan pada sari dari jeruk nipis maupun jeruk sambal. Pada uji Alkaloid ini di dalamnya terdapat atom nitrogen yang bersifat lone pair electron. Apabila pasangan ion tersebut berinteraksi dengan ion logan akan membentuk ikatan kovalen koordinat (McMurry, 2004).
Proses pembentukan alkaloid pada pereaksi Mayer diperkirakan karena nitrogen pada alkaloid akan membentuk ikatan ion logam $\mathrm{K}^{+}$dari kalium tetraiodomerkurat (II) sehingga terbentuk endapan. Endapan inilah yang tidak terbentuk pada uji yang dilakukan pada semua fraksi, sehingga dapat dikatakan beberapa sampel negatif terhadap alkaloid dengan 
pereaksi mayer (Dwisari dkk., 2016). Pada uji saponin dapat diketahui bahwa pada ekstrak kulit jeruk nipis, kulit jeruk sambal dan ekstrak biji jeruk nipis menunjukkan hasil yang positif, hal ini ditunjukkan dengan terbentuknya buih setelah perlakuan pada lapisan atas $\pm 2 \mathrm{~cm}$.

Suatu senyawa mengandung saponin karena memiliki permukaan gugus glikosil yang berkarakteristik polar dan gugus steroid dan triterpenoid bersifat nonpolar. Senyawa yang memiliki gugus polar dan nonpolar akan bersifat aktif apabila terdapat keberadaan air permukaan sehingga saat dikocok dengan air saponin dapat membentuk misel, dimana struktur polar akan menghadap ke luar sedangkan gugus nonpolar akan menghadap ke dalam. Pada kondisi inilah saponin akan berbentuk seperti busa (Sangi dkk., 2008). Sedangkan pada sampel yang lain tidak menunjukkan hal yang sama. Seluruh sampel uji pada metode tabung tidak ditemukan kandungan steroid dan terpenoid yang ditunjukkan dengan hasil negatif. Berdasarkan hasil pengujian steroid tidak ditemukan cincin biru kehijauan menandakan dan pada terpenoid tidak terbentuk warna merah jingga.

\section{Hasil pengukuran parameter non spesifik ekstrak}

Adapun hasil pengukuran parameter non spesifik ekstrak meliputi kadar sari larut air kadar air, kadar abu, susut pengeringan, abu tidak larut asam, dan kadar sari larut etanol seperti ditunjukkan pada Tabel 3.

Tabel 3. Data parameter non spesifik ekstrak etanol 60\% dan air dari C. amblycarpa (L), C. sinensis (O.), dan $C$. aurantifolia $(\mathrm{S}$.

\begin{tabular}{cccccccc}
\hline No. & Ekstrak & $\begin{array}{c}\text { Susut } \\
\text { pengeringan }(\%)\end{array}$ & $\begin{array}{c}\text { Kadar air } \\
(\%)\end{array}$ & $\begin{array}{c}\text { Kadar } \\
\text { abu }(\%)\end{array}$ & $\begin{array}{c}\text { Abu tidak } \\
\text { larut asam }(\%)\end{array}$ & $\begin{array}{c}\text { Abu tidak } \\
\text { larut air }(\%)\end{array}$ & $\begin{array}{c}\text { Kadar sari } \\
\text { larut air }(\%)\end{array}$ \\
\hline 1. & AJM & 9,565 & 9,087 & 4,985 & 3,175 & 18,117 & 15,984 \\
2. & BJS & 17,752 & 15,961 & 5,442 & 3,661 & 25,156 & 10,640 \\
3. & KJN & 13,496 & 14,576 & 3,882 & 3,404 & 28,012 & 11,857 \\
4. & AJS & 8,149 & 8,024 & 2,722 & 1,903 & 20,460 & 15,647 \\
5. & AJN & 9,748 & 9,443 & 4,183 & 1,991 & 14,858 & 16,157 \\
6. & KJS & 15,413 & 14,661 & 2,881 & 0,929 & 20,209 & 16,329 \\
7. & BJN & 15,002 & 15,708 & 3,333 & 1,686 & 21,329 & 16,749 \\
\hline
\end{tabular}

Berdasarkan pada Table 3 kadar air serbuk simplisia pada ekstrak etanol BJM $(22,420 \% \mathrm{~b} / \mathrm{b})$, KJM (15,708\% b/b), KJS (14,661\% b/b), BJS $(15,961 \%$ b/b), KJN (14,576\% b/b), namun untuk kadar AJM, AJS dan AJN dibawah $10 \%$ perbedaan hasil tersebut dapat disebabkan adanya perbedaan cara pengeringan yang dilakukan dan karena karaktersitik ekstrak yang bersifat esktrak kental. Pada air jeruk metode pengeringan yang digunakan dengan metode freeze dry. Berdasarkan pada referensi yang sudah ditetapkan untuk kadar air dipersyaratkan kurang dari $10 \%$. Kadar air simplisia dan ekstrak etanol kulit dan biji jeruk akan memiliki stabilitas yang baik apabila kandungannya kurang dari 10\%. Kadar tersebut terbukti dapat menghambat pertumbuhan jamur dan kapang serta dapat meningkatkan kualitas ekstrak yang diperoleh (Zainab dkk., 2016). Berdasarkan data WHO menunjukkan bahwa kadar air yang tinggi dapat menyebabkan reaksi enzimatis dan munculnya mikroba sehingga menyebabkan penurunan kualitas simplisia (World Health Organization, 1998).

Kadar abu total menggambarkan adanya kandungan mineral internal dan eksternal pada serbuk maupun ekstrak yang diperoleh dari preparasi awal hingga diperoleh sampel ekstrak yang mana metode ini didasarkan atas pemanasan sampel pada temperatur dimana senyawa organik dan turunannya terdestruksi dan menguap (Direktorat Pengawasan Obat Tradisional, 2000). Berdasarkan data yang diperoleh pada Tabel 3 tersebut kadar abu seluruh sampel rata-rata dibawah 5\% yakni pada rentang 2,722 - 5,442\% menunjukkan bahwa kandungan anorganik di dalam ekstrak sudah relatif rendah karena sebagian besar tidak melebihi ketentuan yang ditetapkan sebesar 5\% (Zainab dkk., 2016).

Berdasarkan data pada Tabel 3 menunjukkan bahwa kadar abu tidak larut asam berada pada rentang 0,929 - 3,661\%. Abu yang tidak larut asam adalah residu yang diperoleh setelah memanaskan total abu dengan diencerkan menggunakan asam klorida. Kadar abu tidak larut asam digunakan untuk melihat gambaran terutama keberadaan silica yang terdapat dalam sampel yang dapat bersumber dari pasir dan tanah mengandung silika (World Health Organization, 1998). Kadar abu dalam suatu ekstrak tanaman harus seminimal mungkin untuk mencegah terjadinya hal yang tidak diinginkan. Kadar sari larut air merupakan gambaran metabolit sekunder yang terlarut di dalam air. 
Berdasarkan data yang diperoleh diketahui bahwa sari larut air berada pada rentang 10,640 - 16,749\%. Kandungan metabolit sekunder sampel kulit, biji dan air C. amblycarpa (L.), C. sinensis(O.), dan $C$. aurantifolia (S.) dapat dilihat pada Tabel 4 berikut.

Tabel 4. Kandungan metabolit sekunder sampel kulit, biji dan air C. amblycarpa (L.), C. sinensis(O.), dan $C$. aurantifolia (S.) dengan menggunakan metode tabung

\begin{tabular}{|c|c|c|c|c|c|c|c|c|}
\hline Parameter & Pustaka & KJN & KJS & BJS & BJN & $\overline{A J N}$ & AJS & AJM \\
\hline $\begin{array}{l}\text { Alkaloid } \\
\text { (Mayer) }\end{array}$ & $\begin{array}{l}\text { Terbentuk endapan berwarna } \\
\text { kuning }\end{array}$ & + & + & + & + & - & - & - \\
\hline Fenolik & $\begin{array}{c}\text { Terbentuk warna biru, hijau, merah } \\
\text { atau ungu menunjukkan } \\
\text { keberadaan senyawa fenol }\end{array}$ & + & + & + & + & + & + & + \\
\hline Flavonoid & $\begin{array}{l}\text { Perubahan warna merah, kuning } \\
\text { atau jingga menunjukkan adanya } \\
\text { flavonoid }\end{array}$ & + & + & + & + & + & + & + \\
\hline Saponin & $\begin{array}{c}\text { Terbentuk sabun setinggi } 2 \mathrm{~cm} \\
\text { pada lapisan atas }\end{array}$ & + & + & - & + & - & - & - \\
\hline Steroid & $\begin{array}{l}\text { Terbentuknya cincin biru kehijauan } \\
\text { menandakan adanya steroid }\end{array}$ & - & - & - & - & - & - & - \\
\hline Terpenoid & $\begin{array}{l}\text { Membentuk warna merah jingga } \\
\text { untuk analisis triterpenoid }\end{array}$ & - & - & - & - & - & - & - \\
\hline
\end{tabular}

Keterangan: (+) Positif; (-) Negatif

\section{KESIMPULAN}

Ekstrak etanol $60 \%$ kulit dan biji serta air pada buah jeruk manis (Citrus amblycarpa (L)), jeruk nipis (Citrus aurantifolia (S.)), dan jeruk sambal (Citrus sinensis (O.)) dengan nilai rendemen tertinggi diperoleh pada ekstrak etanol $60 \%$ biji jeruk sambal dengan rendemen yang dihasilkan sebesar 25,28\%. Seluruh sampel mengandung senyawa fenolik dan flavonoid pada uji tabung. Pada uji KLT fase diam silica gel 60 F 254 untuk identifikasi saponin dengan fase gerak kloroform : methanol : air (64: 50 : 1) menggunakan penampak bercak LiebermannBurchard, dan identifikasi flavonoid menggunakan fase gerak asam asetat glasial : asam formiat : air : etil asetat (11: $11: 27: 100)$ dengan penampak bercak sitroborat, pada kedua senyawa tersebut menunjukkan reaksi positif pada seluruh sampel uji. Serta kadar abu seluruh sampel rata-rata dibawah 5\% yakni pada rentang $2,722-5,442 \%$.

\section{UCAPAN TERIMA KASIH}

Terima kasih kami ucapkan kepada Fakultas Kedokteran Universitas Tanjungpura Pontianak atas dukungan dana yang diberikan untuk menuntaskan penelitian ini.

\section{DAFTAR PUSTAKA}

Al-Maliki, A. D. M. (2011). Isolation and Identification of Phenolic Compounds from Elettaria Cardamomum Seeds and Study of
Their Medicinal Activity Against Pathogenic Bacteria of Prostate Gland. Journal of Missan Researches; 8; 13-35.

Apraj, V., Thakur, N. D., Bhagwat, A., Mallya, R., Sawant, L. \& Pandita, N. (2011). Pharmacognostic and Phytochemical Evaluation of Citrus aurantifolia (Christm) Swingle PEEL. Pharmacognosy Journal; 3; 70-76.

Challice, J. (1984). Techniques of Flavonoid Identification. London: Academic Press.

Direktorat Jenderal Bina Kefarmasian dan Alat Kesehatan. (2008). Farmakope Herbal Indonesia (1st ed.). Jakarta: Departemen Kesehatan Republik Indonesia.

Direktorat Pengawasan Obat Tradisional. (2000). Parameter Standar Umum Ekstrak Tumbuhan Obat (1st ed.). Jakarta: Departemen Kesehatan Republik Indonesia.

Do, Q. D., Angkawijaya, A. E., Tran-Nguyen, P. L., Huynh, L. H., Soetaredjo, F. D., Ismadji, S. \& Ju. Y. (2014). Effect of Extraction Solvent on Total Phenol Content, Total Flavonoid Content, and Antioxidant Activity of Limnophila aromatica. Journal of Food and Drug Analysis; 22; 296-302.

Dwisari, F., Alimuddin, A. H. \& Harlia. 2016. Isolasi dan Karakterisasi Senyawa Terpenoid Ekstrak Metanol Akar Pohon Kayu Buta-Buta 
(excoecaria agallocha L.). Jurnal Kimia Khatulistiwa; 5; 25-30.

Etebu, E. \& Nwauzoma. A. B. 2014. A Review on Sweet Orange (Citrus sinensis L Osbeck): Health, Diseases and Management. American Journal of Research Communication; 2; 3370.

Fauziah, D. T. (2006). Identifikasi dan Skrining Aktivitas Antibakteri dan Antijamur Ekstrak Etanol Rimpang Kunci Pepet (Kaempferia Rotunda L.). Tesis; Fakultas Farmasi Universitas Setia Budi, Surakarta.

Farnsworth, N. R. (1966). Biological and Phytochemical Screening of Plants. Journal of Pharmaceutical Sciences; 55; 225-276.

Harborne, J. B., Sudiro, I., Padmawinata, K. \& Niksolihin, S. (1996). Metode Fitokimia: Penuntun Cara Modern Menganalisis Tumbuhan. Bandung: Institut Teknologi Bandung.

Handayani, S., Sunarto \& Kritianingrum, S. (2005). Kromatografi Lapis Tipis untuk Penentuan Kadar Hesperidin dalam Kulit Buah Jeruk. Jurnal Penelitian Saintek; 10; 53-68.

Hidayah, W. W., Kusrini, D. \& Fachriyah. E. (2016). Isolasi, Identifikasi Senyawa Steroid dari Daun Getih-Getihan (rivina humilis L.) dan Uji Aktivitas Sebagai Antibakteri. Jurnal Kimia Sains dan Aplikasi; 19; 32.

Irianti, T., Murti, Y. B., Kanistri, D. N., Pratiwi, D. R., Kuswandi \& Anggar, R. (2016). Dpph Radical Scavenging Activity of Aqueous Fraction from Ethanolic Extract of Talok Fruit (muntingia calabura L.). Traditional Medicine Journal; 21; 38-47.

Karthika K, Jamuna S. \& Paulsamy S. (2014). TLC and HPTLC Fingerprint Profiles of Different Bioactive Components from the Tuber of Solena amplexicaulis. Journal of Pharmacognosy and Phytochemistry; 3; 198206.

Kaya, B. Y., Menemen, \& Fz Saltan. (2012). Flavonoid Compounds Identified in Alchemilla l. Species Collected in the North-Eastern Black Sea Region of Turkey. African Journal of Traditional, Complementary and Alternative Medicines; 9; 418-425.

Kelebek, H., Canbas, A., Selli S., Saucier, C., Jourdes, M. \& Glories, Y. (2006). Effects of Different Maceration Times and Pectolytic Enzyme
Addition on the Anthocyanin Composition of Vitis Vinifera Cv. Kalecik Karasi Wines. Journal of Food Engineering; 77; 1012-1017.

Lota, M., Serra, D. D. R., Tomi, F., Jacquemond, C. \& Casanova, J. (2002). Volatile Components of Peel and Leaf Oils of Lemon and Lime Species. Journal of Agricultural and Food Chemistry; 50; 796-805.

Mir, M. A., Parihar, K., Tabasum, U. \& Kumari, E. (2016). Estimation of Alkaloid, Saponin and Flavonoid, Content in Various Extracts of crocus sativa. Journal of Medicinal Plants Studies; 4; 171-174.

McMurry, J. (2004). Organic Chemistry (6 $6^{\text {th }}$ ed.). Belmont: Thomson-Brooks/Cole.

Narang, N. \& Jiraungkoorskul, W. (2016). Anticancer Activity of Key Lime, Citrus aurantifolia. Pharmacognosy Reviews; 10; 118.

Nurhasnawati, H., Sukarmi \& Handayani, F. (2017). Perbandingan Metode Ekstraksi Maserasi dan Sokletasi terhadap Aktivitas Antioksidan Ekstrak Etanol Daun Jambu Bol (Syzygium malaccense L.). Jurnal Ilmiah Manuntung; 3; 91-95.

Pamungkas, K. \& Murrukmihadi, M. (2015). Isolasi dan Penetapan Kadar Alkaloid Ekstrak Etanolik Bunga Kembang Sepatu (Hibiscus rosa-sinensis L.) secara Spektrodensitometri. Traditional Medicine Journal; 20; 112-118.

Phillipson, J. D. \& Hemingway, S. R. (1975). Chromatographic and Spectroscopic Methods for the Identification of Alkaloids from Herbarium Samples of the Genus Uncaria. Journal of Chromatography A; 105; 163-78.

Poulose, Shibu M., Edward, D. H. \& Bhimanagouda, S. P. (2005). Citrus Limonoids Induce Apoptosis in Human Neuroblastoma Cells and Have Radical Scavenging Activity. The Journal of Nutrition; 135; 870-77.

Pusat Data dan Sistem Informasi Pertanian. (2015). Outlook Komoditas Pertanian Subsektor Hortikultura Jeruk by Sekretariat Jenderal Kementerian Pertanian. http://epublikasi.setjen.pertanian.go.id/epublik asi/outlook/2015/Hortikultura/Outlook\%20Jer uk\%202015/files/assets/common/downloads/ Outlook\%20Jeruk\%202015.pdf. Accessed: 17 Februari 2019.

Putra, G. M. D., Satriawati, D. A., Astuti, N. K. W. \& Yadnya-Putra, A. A. G. R.. (2018). 
Standarisasi dan Skrining Fitokimia Ekstrak Etanol $70 \%$ Daun Jeruk Limau (Citrus amblycarpa (hassk.) Osche). Jurnal Kimia; 12; 187-194.

Rao, U. S. M. (2016). Phytochemical Screening, Total Flavonoid and Phenolic Content Assays of Various Solvent Extracts of Tepal of musa paradisiaca. Malaysian Journal of Analytical Science; 20; 1181-90.

Safitri, D. A. (2016). Pemisahan Senyawa Steroid Fraksi Etil Asetat Mikroalga Chlorella sp. Menggunakan Kromatografi Kolom Cara Basah dan Kering. Skripsi; Fakultas Sains dan Teknologi Universitas Islam Negeri Maulana Malik Ibrahim, Malang.

Sangi, M., Runtuwene, M. R. J., Simbala, H. E. I. \& Makang, V. M. A. 2008. Analisis Fitokimia Tumbuhan Obat di Kabupaten Minahasa Utara. Chemistry Progress; 1; 47-53.

Santosa, D. \& Haresmita, P. P. (2015). Antioxidant Activity Determination Garcinia dulcis (Roxb.) Kurz, Blumeamollis (D. Don) Merr., Siegesbeckia orientalis L., and Salvia riparia H.B.K Which Collected from Taman Nasional Gunung Merapi Using DPPH (2,2-Diphenyl1-Pikril -Hidrazil) and Thin Layer. Traditional Medicine Journal; 20; 28-36.

Sopianti, D. S. (2018). Skrining Fitokimia dan Profil KLT Metabolit Sekunder dari Daun RukuRuku (Ocimum tenulflorum l.) dan Daun Kemangi (Ocimum sanctum l). Scientia: Jurnal Farmasi Dan Kesehatan; 8; 44.

Sun, Y., Qiao, L., Shen, Y., Jiang, P., Chen, J. \& Ye, X. (2013). Phytochemical Profile and
Antioxidant Activity of Physiological Drop of Citrus Fruits. Journal of Food Science; 78; C37-42.

Truong, D., Nguyen, D. H., Ta, N. T. A., Bui, A. V., Do, T. H. \& Nguyen, H. C. (2019). Evaluation of the Use of Different Solvents for Phytochemical Constituents, Antioxidants, and In Vitro Anti-Inflammatory Activities of Severinia buxifolia. Journal of Food Quality; 2019; 1-9.

Wagner, H. \& Bladt. S. (1996). Plant Drug Analysis: A Thin Layer Chromatography Atlas. Berlin: Springer-Verlag Berlin Heidelberg.

Wang, S, Yang, C., Tu, H., Zhou, K., Liu, X., Cheng, Y., Luo, J., Deng, X., Zhang, H. \& Xu, J. (2017). Characterization and Metabolic Diversity of Flavonoids in Citrus Species. Scientific Reports; 7; 10549.

World Health Organization. (1998). Quality Control Methods for Medicinal Plant Materials. Geneva: World Health Organization.

Xiao, J., Capanoglu, E., Jassbi, A. R. \& Miron, A., (2016). Advance on the Flavonoid C Glycosides and Health Benefits. Critical Reviews in Food Science and Nutrition; 56; S29-45.

Zainab, Sulistyani, N. \& Anisaningrum. (2016). Penetapan Parameter Standardisasi Non Spesifik dan Spesifik Ekstrak Daun Pacar Kuku (Lawsonia inermis L.). Media Farmasi; 13; 212-26. 